\title{
Towards a profile of sustainable energy in Baja California, Mexico, for 2011-2025 from an environmental perspective
}

\author{
M. Quintero-Núñez ${ }^{1}$, G., Muñoz-Meléndez ${ }^{2}$, \\ H. E. Campbell-Ramirez ${ }^{1}$ \& E. Díaz-Gonzalez ${ }^{2}$ \\ ${ }^{1}$ Instituto de Ingeniería-UABC, Mexicali, Mexico \\ ${ }^{2}$ Colegio de la Frontera Norte, Baja California, Mexico
}

\begin{abstract}
The energy sector is fundamental for the development of Baja California (BC). At the end of 2008 the installed capacity of electricity in BC was 3,360 MW, which represents $7.191 \%$ of the total capacity of the country. The technology employed in the generation of power in the state of $\mathrm{BC}$ according to its importance is geothermics (720 MW), combined cycle (498 MW) and conventional thermoelectrics $(620 \mathrm{MW})$, all of which are managed by the Mexican utility company Compañia Federal de Electricidad (CFE), and combined cycle (1500 MW) generated by independent producers. The environmental impacts associated with the electric sector in Baja California are given mainly in the form of atmospheric emissions from the consumption of fuel. Other environmental impacts are associated with: 1) the use of considerable volumes of water, 2) the generation of residuals and to a lesser degree 3) the emission of residual heat, noise, vibrations and sinking (in geothermal fields). To make the energy sector more sustainable, renewable energy resources have begun to be exploited in the state using wind (10 MW), photovoltaics (5 MW) and wave $(3 \mathrm{MW})$ power with an optimistic plan of increasing capacity in the medium term . The objective of this work is to describe the five indicators of energy sustainability in the environmental dimension for the state of $\mathrm{BC}$ in relation to climate change, air, water quality and management of solid residuals. Keywords: energy sustainability, Baja California, Mexico, renewable resources, energy indicators.
\end{abstract}




\section{Introduction}

The energy sector is one of the elements of the economy that projects better the federal principle that organizes politically Mexico. Baja California has an energy base integrated by oil derivatives and electricity. The demand of hydrocarbons is fulfilled by Petroleos Mexicanos (PEMEX), the state monopoly in charge of the exploitation of crude oil, apart from processing oil and importing gasoline and diesel, mainly.

On the other side, in the electric sector the opportunities for energy planning are greater for the state of Baja California, since the operation of the electric systems is the responsibility of other state monopoly, the Comision Federal de Electricidad (CFE). In the ambit of electric generation Baja California has installed various private and public energy plants that exploit the primary sources of energy in its territory and, by considering that the state is not linked to the interconnected system of the national electric grid as much as with the USA electric system, the regional electric market is in a certain degree autonomous in reference to the offer and demand levels of the service, not as much as the prices scheme utilized for the consumption of electricity.

The lack of connection to the national electric net makes compulsory to the state to generate its own energy to satisfy the growing demand of a population in constant growth and the dynamic of the economic activity is based in a good measure on multinational enterprises that export their production to the United States, that for this region has an strategic importance for the macroeconomic stability and the development of the country.

The electric sector in Baja California covers a wide spectrum in the economic activity, from the exploitation of natural resources up to its final utilization in the industrial sector, services, residential and transportation. It is also important to promote the use of renewable sources of energy in particular the wind, solar and microhydroelectric. It is also relevant as an objective the energy saving and the energy efficiency in urban areas, particularly actions of this nature apply to new housing schemes and human infrastructure.

The environmental implications from the energy consumption in general and the electricity generation in particular, open for the society and the state authorities a space of opportunities to improve the social wellbeing through the reduction of emissions, the mitigation of nocive environmental impacts due to the generation and transmission of electricity, and the utilization of renewable sources of energy that diminish the overexploitation of natural capital in Baja California.

The use of environmental indicators applied to power plants helps to establish certain criteria to judge the operation of the energy system that fulfilled the requirement of a clean interaction with its surrounding to put aside the possibilities of pollution to the environment as to cause a health effect to the communities established in the area. 


\section{Characteristics of Baja California}

The state of Baja California (Fig. 1) is located in the northwest part of the peninsula of the same name with approximately $500 \mathrm{~km}$ length from the international line with California, USA ( $33^{\circ}$ latitude North) down to parallel $28^{\circ}$ in the south. It has a surface of $70,113 \mathrm{~km}^{2}$ which represent $3.75 \%$ of the total surface of the country. It is formed by mountains, hillsides, central valleys and coasts, besides a very discontinuous littoral on the Pacific Ocean.

The state of Baja California is characterised by the existence of two main meteorological regimes that divide the climate: a warm and dry during the spring, summer and the beginning of the fall, and the other in winter with relatively humid and slightly cold [1].

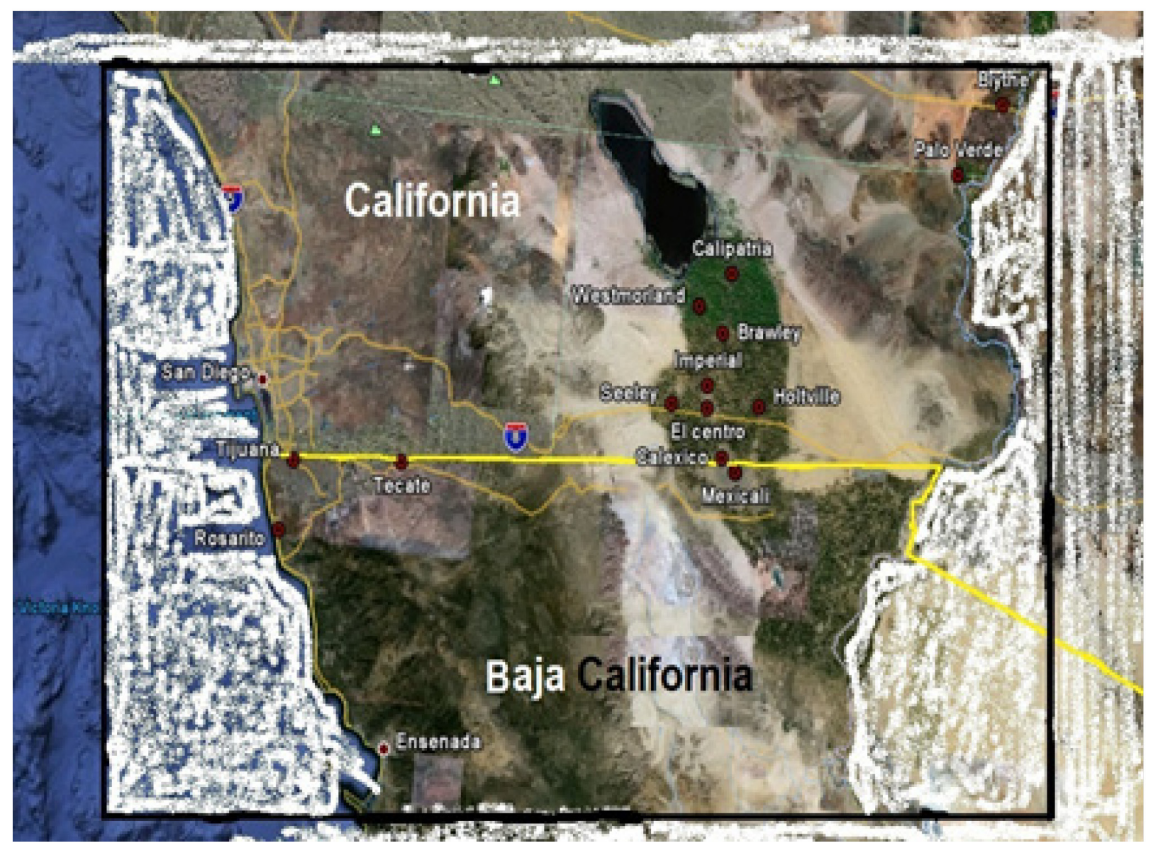

Figure 1: The state of Baja California is located in the northwest of México.

\subsection{Power generation in Baja California}

The current electric infrastructure in Baja California (see Figure 2) consists of four power generating plants, several small plants and an adequate system of transmission lines, concentrated in two zones: the Valley and the Coast. The grid is connected to California (USA) using four lines of 230 kilovolts (KV) one of them is located in Tijuana, and three in Mexicali. The four grids belong to American companies: Sempra, Intergen and San Diego Gas \& Electric. 


\section{POWER GENERATION IN BAJA CALIFORNIA}

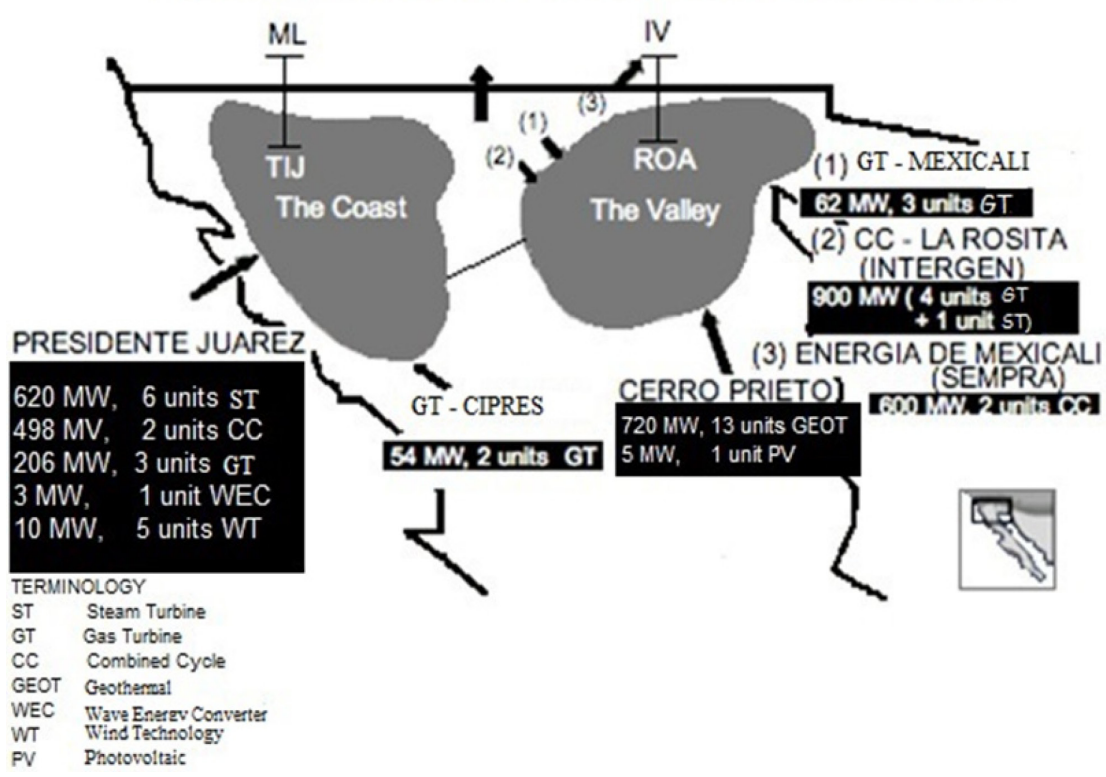

Source: CFE, 2013

Figure 2: $\quad$ Power generation in Baja California.

The only source of indigenous energy utilized at a large scale is geothermal, fueling the power plant located at Cerro Prieto, south of Mexicali with a plate capacity of $720 \mathrm{MW}$. In Baja California, there is also a natural gas fired, combined cycle plant, "The President Juarez" Central Power Plant, producing $1,118 \mathrm{MW}$ that is located at the municipality of Rosarito, that started operations in 2001. In addition to these two power plants, there are two combined cycle plants in Mexicali (La Rosita y La Termoeléctrica de Mexicali operating since 2003), CFE operates ten back up units, distributed in Tijuana, Ensenada and Mexicali, with an installed capacity of $322 \mathrm{MW}$.

\subsection{Power transmission lines at the $\mathrm{CA} / \mathrm{BC}$ border}

The two transmission lines connecting the Mexicali export plants to Imperial Valley are each capable of carrying up to 1,200 MW, although currently the plants serving these transmission lines have a capacity of $600 \mathrm{MW}$ each. However, the only outlet for this power at present is San Diego, along the $500 \mathrm{kV}$ transmission trunk line known as the Southwest Power Link (SWPL) that connects power plants in western Arizona (Palo Verde) with San Diego. On peak demand days the SWPL operates near its 1,300 MW carrying capacity, limiting the amount of power that can be exported from Mexico. The capacity of the SWPL will be increased over the next few years to increase transmission capacity to $1,900 \mathrm{MW}$. 


\subsection{Natural gas pipelines}

Baja California does not exploit natural gas (NG) neither produce it and are not known in the region proven or probable reserves; however in the last decade its consumption has increased. Reports by the Secretary of Energy (SENER) of Mexico show that the demand of NG increased from 13.9 million cubic feet /daily in 2005 to 256.4 millions in 2009 , that is to say registers an extraordinary growth of $38 \%$ annual average in that period [2].

Baja California is not connected to the National Pipeline System (NPS) and for that reason has not access to the national production of NG. Thus, the regional consumption is supplied by the importation through pipelines and by a liquefied natural gas (LNG) terminal located $30 \mathrm{~km}$ away from Ensenada, at Costa Azul with a capacity of $320,000 \mathrm{~m}^{3}$. The electric sector is the major consumer of NG in Baja California, with 93\% of total consumption in 2009.

The environmental aspects associated with LNG are known regularly as those caused for the generation of emissions to the air, including gases that produced greenhouse effects. Apart from the combustion, it may produce environmental impacts during the discharge and transport of $\mathrm{LNG}$, as this fuel is made up of $95 \%$ methane, that may diffuse in the form of a vapor cloud -inflammable-or leaks in pipes and storage tanks.

\subsection{Oil products}

Not a single oil product is processed in Baja California; therefore there does not exist basic infrastructure of the Refining National System in the state; however the oil products are consumed widely in the region based on an efficient distribution infrastructure.

The supply of these fuels to the region is very wide in various types of products: gasoline, $\mathrm{NG}$, LPG, fuel oil, diesel, etc. $65 \%$ of oil products are imported (gasoline y diesel), including all natural gas $[3,4]$.

The transportation system is the main consumer of gasoline in Baja California, which consumed $75 \%$ of the total supplied to the region in 2005 . The growing demand of gasoline in the last years derived from the behavior of the vehicle market and the policy of prices of these fuels. The distribution of the vehicle park and the quality of the vehicle fleet explain in a great deal the level of gasoline demand in the state.

\section{Environmental indicators}

In this section are detailed the 5 indicators of energy sustainability in the environment dimension for the state of Baja California. The social and the economic dimensions are described elsewhere [5]. The estimation of the indicators followed the methodologies established for the Atomic Energy International Organization, United Nations Department of Economics and Social Business, EUROSTAT and the European Agency for the Environment [6]. 


\subsection{Climate change}

\subsubsection{ENV1 Emissions of greenhouse gases (GHG) for the production and use of the energy per capita and by unit of GDP}

The percentage contributions of Greenhouse Gases Emissions (GHGE) were: $59.1 \%$ for transportation (in particular the combustion of gasoline), $28 \%$ due to power generation (fuel oil up to 2003 and NG since then), 3.39\% caused by the industrial sector (diesel and LPG up to 1998, when gas was included in the energy matrix), $1.71 \%$ by the agricultural sector (diesel) $1.19 \%$ by the commerce and services sectors and $6.01 \%$ by the residential sector (in the last cases by the use of LPG).

In Baja California the average emissions of GHG per capita in the last years has been $4.1 \mathrm{tCO}_{2}$ eq. per capita, in contrast in Mexico the value was $3.97 \mathrm{tCO}_{2}$ eq per capita in 2006. In the state there was an important increment of GHGE per inhabitant in 1991. It is at the start of this year and up to 2005 that the value fluctuates around $4.0 \mathrm{tCO}_{2}$ eq per capita. It is observed a moderate diminution after 1994 and up to 1998, the effect may reflect the reduction of consumption of electricity and fuel due to the economic crisis of that period. From 1999 and up to 2002 the emissions become stable around the average value for the period. For a couple of years there was a slight down fall in the emissions. However, from 2005 the value increases to $4.6 \mathrm{tCO}_{2} \mathrm{eq}$ to remained around that figure for the following three years and have a decrease in 2010 , possible due to the reduction of the consumption caused by the economic crisis.

On the other hand, the GHG emissions per monetary unit in the period 1993 to 2009 showed a tendency to fall, this result suggests that although the emissions (per consumption and electricity) and the price of the fuels -specially of those derived from oil- increased, it was the prices that increased in an accelerated form.

According to the Galindo report [7], the energy is a fundamental input in any economy, however, it also represents one of the main sources of the various greenhouse gases. In this respect, it is observed that exists a strong association between the level of income of an economy and the consumption of energy. Even though, it has being observed during recent years, a rate of energy decoupling and decarbonization in the Mexican economy that has been insufficient for the moment and an any case should be deepened.

\subsection{Air quality}

\subsubsection{ENV2 Environmental concentrations of atmospheric pollutants in urban areas Tijuana and Rosarito}

For the urban areas of the cities of Tijuana and Rosarito it was estimated that the pollutant that is emitted in increasing amounts is $\mathrm{CO}$ with 77,216 tons/year, following up PM10 with 33,783, and then the VOCs, 29,777.70; the $\mathrm{NO}_{x}$, 22,980.10; the $\mathrm{PM}_{2.5}, 5,930.10$; the $\mathrm{SO}_{2}, 5,2040$; the $\mathrm{CH}_{4} 4,578.90$ and finally the $\mathrm{NH}_{3}$ with $1,575.70$ tons/year. It shows that the main emitter of $\mathrm{CH}_{4}$ was the contribution of the area sources that equally participates significantly in the emissions of $\mathrm{NH}_{3}$ and VOCs; and principal emissions of $\mathrm{PM}_{10}$ and $\mathrm{PM}_{2.5}$. On the 
other hand the road mobile sources are the main emitters of $\mathrm{CO}$ and $\mathrm{NO}_{\mathrm{x}}$. In relation to fixed sources, these are identified as the principal sources of $\mathrm{CO}$ and $\mathrm{NO}_{\mathrm{x}}$. In relation to fixed sources, these are identified as the principal emitters of $\mathrm{SO}_{2}$. Finally, it has to be mentioned that the non -road mobile sources have low emission of $\mathrm{PM}_{10}, \mathrm{PM}_{2.5}, \mathrm{CO}, \mathrm{NO}_{\mathrm{x}}$ and $\mathrm{NH}_{3}$, nonetheless should not be ignored. Mexicali.

The pollutant that is emitted in vast amounts is $\mathrm{CO}$ with 78,727 ton/year, and followed by the $\mathrm{PM}_{10}$ with 48,827; the emissions of the $\mathrm{NO}_{\mathrm{x}}$ and the COV's were 25,979 and 23,183, respectively. The emissions generated in smaller amounts were $\mathrm{CH}_{4}(11,030), \mathrm{NH}_{3}(8,408), \mathrm{PM}_{2.5}(7,331)$ and $\mathrm{SO}_{2}$ in 4,522 ton/year.

\subsubsection{ENV3 Emissions of atmospheric pollutants proceeding from the energy systems}

It was observed that in 1990 were emitted 19,000 tons of $\mathrm{SO}_{2}$, being generated $94 \%$ of it by the combustion of fuel oil in the coastal zone. From 2001 it was reduced the participation of this fuel being substituted by natural gas, which caused that emissions of $\mathrm{SO}_{2}$ diminished to 8,300 tons for 2004. The relative emissions of $\mathrm{SO}_{2}$ have diminished from $2.88 \mathrm{~kg} / \mathrm{MWh}$ of electricity generated in 1990 , to $0.80 \mathrm{~kg} / \mathrm{MWh}$ in 2010 . On the other hand, the emissions of $\mathrm{NO}_{\mathrm{x}}$, were estimated in 6,000 tons corresponding $63 \%$ to the coastal zone up to 2010 . The relative emissions were increased from $0.39 \mathrm{~kg} / \mathrm{MWh}$ in 1990 to $0.49 \mathrm{~kg} / \mathrm{MWh}$ in 2010 .

At a national level and according to the Special Program of Climate Change 2009-2012, published in the Official Diary of the Nation in 2009, the generation processes and use of energy constitute the principal emitters of GHG, with $60.1 \%$ of total emissions, which in 2006 were dimensioned in 715.3 millions of tons of carbon dioxide $\left(\mathrm{CO}_{2}\right)$, methane $\left(\mathrm{CH}_{4}\right)$ and nitrous oxide $\left(\mathrm{N}_{2} \mathrm{O}\right)$, expressed in terms of $\mathrm{CO}_{2}$ eq. In particular, in the process of generation of electric energy were emitted $112.5 \mathrm{MtCO} 2 \mathrm{e}$, which represents nearly $16 \%$ of the national total. This is as a result mainly of the composition of the power generation plants of Mexico, where fossil fuels participate in more than $75 \%$ of the generation of electricity for public service.

\subsection{Water quality}

\subsubsection{ENV4 Discharge of pollutants in liquid effluents from the energy systems, including oil discharges}

In Baja California, the quantity of liquid effluents generated in the conventional thermoelectric plants of Rosarito during the operations phase, could be of 94.651 $\mathrm{m}^{3} / \mathrm{h}$. The typical composition to be found of the effluent in the cooling tower in the thermoelectric power plants, of combined cycle could be: total dissolved solids (350-880 mg/l), pH (7.8-8.8), suspended solids (100 mg/l) oils and greases $(5 \mathrm{mg} / \mathrm{l})$ free chlorine $(0.3 \mathrm{mg} / \mathrm{l})$, with a temperature higher than $10^{\circ} \mathrm{C}$ (Shandilya et al. [8]). On the other hand the expected typical composition of the effluent of the boiler of a unit of $250 \mathrm{MW}$ could be of total dissolved solids (166 mg/l), pH 
(8.9), suspended solids $(100 \mathrm{mg} / \mathrm{l})$ oils and greases $(0.2 \mathrm{mg} / \mathrm{l})$ silica as $\mathrm{SiO}_{2}(0.2$ $\mathrm{mg} / \mathrm{l})$ with a temperature higher than $10^{\circ} \mathrm{C}[8]$.

At Cerro Prieto, the operations at the geothermal field produce around 6,400 tons per hour of geothermal residual brine, which is transported and disposed of in an evaporation lagoon that covers an area of 7.2 square miles (18.6 square kilometers). In the same site an annual average of $88 \%$ of all the residual brines are disposed of, polluting the soil and potentially the aquifer of the region. The reinjection of geothermal residual brine is practiced in some dead wells $(60 \%$ of the geothermal residual brine is reinjected).

The chemical composition of the geothermal waters at Cerro prieto have been reported that contain the following ions in the specified concentrations: $350 \mathrm{mg} / \mathrm{l}$ of sodium, $1,520 \mathrm{mg} / \mathrm{l}$ of potassium, $528 \mathrm{mg} / 1$ of calcium, $174 \mathrm{mg} / \mathrm{l}$ of boron, 650 $\mathrm{mg} / \mathrm{l}$ of silicon oxide, $11 \mathrm{mg} / \mathrm{l}$ of bicarbonate and 14,200 mg/l of chlorine [9].

\subsection{Generation and management of solid residuals}

\subsubsection{ENV 5 Relation of solid residual generation to units of energy produced}

The volume of solid residuals generated depend on the industrial processes, the fuel and the management practices; parameters that vary from plant to plant. As an example is taken the environmental impact assessment of the three turbo gas units of $245 \mathrm{MW}$ in the facilities of the thermoelectric power plant "President Juarez" of Rosarito at the coastal zone. In such a document was reported that the new plant would generate $1 \mathrm{~m}^{3} /$ month of toxic and inflammables residuals in the form of rags impregnated with oil and solvents, which were disposed of in an adequate manner.

If the generation of solid residuals in the turbo gas plant of Rosarito is constant, the indicator shows an improvement as time passes by, that is to say a smaller quantity of residuals generated per unit of electricity produced, from $4.5 \times 10^{-5}$ to $2.5 \times 10^{-5} \mathrm{t} / \mathrm{MMWh}$, from 1992 to 2010 , this reduction, without doubt would result as a function of a efficient practice of residuals management.

\section{Energy prospects to 2025 for Baja California}

The economy of Baja California since 2006 has passed for a period of a deceleration of growth and in 2008 -2009 experimented a recessive phase which was extended to the start of 2010. This caused that the demand of energy was halted if compared to the tendency observed in the stages of economic expansion that suffered the state, for example in the second half of the nineties and the first decade of 2000. Inclusive, situations were given of a reduction in the consumption of electricity as it happens with the commercial sector, where the demand diminished in 2010 respect the observed level in 2003.

This causes that in a perspective of the behavior of the energy sector in the long term, for example since 2003 to 2010, the aggregated growth of the economic activities and the manufacturing industry had presented a moderate 
profile. Taking that into consideration, the projections of the energy demand and offer of the state are based in two possible scenarios in a prospective of 15 years:

a) Business as Usual: BAU that identifies the most probable trajectory given certain determinations of economic policy and based in government strategies in the electric sector. In this scenery the economy will grow in $3.5 \%$ annual average in the future. That is to say, it follows an inertial tendency but without considering the impact of an international recession like the one in 2008-2009 [2, 10, 11].

b) Factual Scenario: FS that includes measures or interventions of public policy to mitigate the energy consumption as much as its implications towards the future taking as a reference the inertial prospective for the period 2011-2025, independently of the variation of the tendency of the state economy $[2,10,11]$.

The scenarios are compared based on the performance of the appropriate sustainable indicators of energy [5]. Starting with the results, product of the analysis of the comparison, are listed various recommendations for the sustainable development of the energy sector in Baja California for the period 2010-2020 in the environmental area.

\subsection{Inertial scenario}

In the short term is expected that the electric sector will increase its installed capacity from 2,042 MW in 2011 to 4,266 MW in 2025, that is at an annual rate of $5.17 \%$. The capacity of the state will be influenced by the interconnection of $300 \mathrm{MW}$ to the national electric grid in 2014. The installed capacity will increase due mainly to the installation of combined cycles of better efficiency $(1,689 \mathrm{MW}$ or $73 \%$ ) and wind mill parks (320 MW or $14 \%$ ).

The fuel of major participation for the generation of electricity will be NG that will grow at the rate of $3.33 \%$, from 269.0 in 2011 to 404.9 millions of cubic feet in 2025. The demand of electricity will also increase, at an annual rate of $5.2 \%$ from 2,237 MW to 3,992 in 2011 and 2025, respectively.

For the transportation sector is expected to continue the exponential increase in the consumption of gasoline, since the vehicle park will grow and the individual car travels will increase. Thus, it is expected that the consumption of gasoline for land transportation will go from 4,273 in 2010 to 6,649 millions of litters per year in 2020, which represent an annual increase of $5.56 \%$.

In environmental terms it is expected that the gradual increase in the deterioration cause by the emission of the transport system will be $123 \%$ higher than the actual and 7 times higher as compared to 1990 [11]). However, some actions in progress will tend to control the atmospheric emissions in area and mobile sources as were mentioned before.

In relation to the environmental improvements, it is estimated that if the actual rhythm of paving the streets under the Integral Paving Program and Air Quality (IPPAQ) by the State de B. C. is maintained, 68,339.2 ton of $\mathrm{PM}_{10}$ could be avoided for 2025, that without considering the contribution of the reduction of particulate matter from the paved streets by the municipalities. On the other hand the state legislation has made compulsory the smog check test which will have an impact in the actual generation of atmospheric emissions. Reductions are 
expected in the order of 209 ton CO, 181 ton VOCs, 159 ton NOx y 4 ton PM for the Tijuana-Rosarito region during the period 2013-2015. Meanwhile, the reduction for the same period for Mexicali would be 20 ton CO, 200 ton COV's, 108 ton. $\mathrm{PM}$ and 4 ton $\mathrm{CH}_{4}$. Considering specifically the emissions of $\mathrm{CO}_{2}$ eq, it is noted that the emissions projected in the state inventory of GHG [12]) for the energy sector, would be reduced with the adoption of the smog check program $89,455.40 \mathrm{tCO}_{2}$ eq [10] as much as for the introduction of electric system using renewable sources of energy that would avoid emissions of 2,231.2 $\mathrm{tCO}_{2} \mathrm{eq}$ during the construction of a 1260 MW capacity wind park instead of using natural gas.

\subsection{Factual scenario}

The conditions of the energy sector for Baja California under a factual scenery for 2011-2025 include a reduction of the participation of the combined cycle in $55 \%(1,268 \mathrm{MW})$; the participation of a mixture of renewable sources of energy under these circumstances will increase to $36 \%(820 \mathrm{MW})$, with the participation of wind power with at least 14\% (320 MW). A small change in terms of contribution to the installed capacity ( $1 \%$ ) but significant in environmental terms is the participation of biogas for the generation of electricity, and perhaps the formalization of photovoltaic electric systems at a small scale.

With all this, the fuel of major participation for the generation of electricity will continue to be natural gas although under the factual scenario will grow moderately going from 269 in 2011 to 305 million cubic feet in 2025. The demand of electricity will also grow in this scenario, although with a reduction of $54 \%$ in the whole period based on an energy efficiency of $54 \%$ in the whole period due to the energy efficiency in the industry and in a lesser degree to thermal insulation at homes.

In the transportation sector is expected to continue the exponential increment in the consumption of gasoline in Baja California, although derived from the implementation of collective mass transport in Tijuana and Mexicali, it is assumed a reduction of 1063.4 millions of litters of gasoline during the period 2011-2020.

In environmental terms, the factual scenario assumes that the smoke check test and paving programs will continue as described in the inertial scenario. Although the atmospheric pollutants do not vary, the GHG emissions will notoriously, due to transportation and power plants atmospheric emissions.

\section{Conclusions}

As it may be appreciated along this work, the development of the energy sector in Baja California is possible under a different scenario derived from the historic tendency.

It is possible a sustainable growth under an alternative scenario at the same time that the economic activities are maintained and promoted; and supply is guaranteed to the population regarding the environment. The scenario hereby 
denominated factual is probable within the actual context, by reinforcing existing current government programs and the start up of postponed plans.

It is recommended to carry out the following activities - all possible to be reached in the period 2011-2025:

In relation to the vehicular fleet:

Considering the exponential increase in the consumption of gasoline by land transportation in Baja California, the growth in the vehicular fleet, as much as the individual car travels and not being opposed by an improve in the efficiency of the vehicles; it is expected that the consumption of the urban transportation reaches 6,649 millions of litters per year in 2020; additionally taking into account that the transport is responsible for $59 \%$ of the GHG emissions, is crucial to design integral programs that include massive transport, the application of the smog check test, the planning of the urban development with a densification approach, establishing annual goals based on the performance of the environmental and energy indicators.

In relation to electricity:

In the generation of electricity is recommended to diminish the internal uses in the process of power production and losses in the process of transmission and distribution by fixing annual goals; mitigating the use of natural gas, by replacing the combined cycle power plants programmed from 2015 to 2025 for systems of renewable energy with probable co-benefits.

Is important to moderate the end use of electricity at homes, and the public sector by a gradual application of energy saving actions and efficient use of energy in the hydraulic, educational and public lighting subsectors, by establishing specific goals in the 6 years periods government developing plants

\section{References}

[1] Alvarez , M. "Climatologia de la Sierra de San Pedro Martir", Desert Fishes Council $15^{\circ}$ Annual Simposio, November 1983.

[2] SENER (Secretaria de Energia). Prospectiva del Mercado de Gas Natural2010-2025. Primera edición. Disponible: http:/www.sener.gob.mx/webSener/res/PE_y_DT/pub. 2010c

[3] Pemex. Memoria de labores, 2009. Dirección Corporativa de Finanzas, México. pp. 214. 2010.

[4] SEDECO (Secretaria de Desarrollo Económico). Guia del inversionista para Baja California. Gobierno del Estado de Baja California. 2008.

[5] Muñoz M. G., Diaz G.E., Campbell R. H., Quintero, N.M. Baja CaliforniaEnergy Profile 2010-2020. Proposal and analysis of energy for the development of state prospectives. USAID Report. Comisión Estatal de Energía de Baja California. Baja Cfa., México, 2012.

[6] Organismo Internacional de Energia Atómica (OIEA), Departamento de Asuntos Económicos y Sociales de las Naciones Unidas (UNDESA),Agencia Internacional de la Energia, EUROSTAT, y la Agencia Europea del Medio Ambiente, Indicadores Energéticos del Desarrollo Sostenible: Directrices y Metodología. OIEA. 2008. 
[7] Galindo, L.M., (Coord.). La Economía del Cambio Climático. Gobierno Federal, SCHP y SEMARNAT, 2009.

[8] Shandilya P., S.S. Phogat, G.S. Mahal, S. Balaji and Sudhir Barthiya. Collection, handling and treatment of liquid effluents in thermal power plants. BHEL Journal,. 27(2), pp. 45-55, 2006.

[9] Hiriart, G. and Del Rio, L. Mexican experience in geothermal power generation. Proceedings of the World Geothermal Congress, Florence, Italy,18-31 May 1995. pp. 2025-2030. 1995.

[10] Galindo Duarte M., Santos Gomez M. A. and Benites Zamora J.L. Primer Reporte de Avances de la Mesa de Transporte Terrestre del Plan Estatal de Acción Climática de Baja California", Secretaría de Protección al Ambiente del Gobierno del Estado de Baja California, 2010.

[11] SENER (Secretaría de Energía). Prospectiva del Sector Eléctrico 20102025, Primera edición, México. Disponiblehttp: //www.sener.gob.mex/ webSener/res/PE_y_Dt/pub/, 2010b

[12] Muñoz Meléndez G. y Vázquez Betania, Inventario de Gases Efecto Invernadero del Estado de Baja California para el Período 19902005, Proyecciones a 2050. El Colegio de la Frontera Norte. 2012. 